\title{
Rethinking agency in International Relations: performativity, performances and actor-networks
}

\author{
Benjamin Braun $^{1}$ (D) Sebastian Schindler $^{2}$ (D) Tobias Wille $^{2}$ (D)
}

Published online: 25 April 2018

(C) Macmillan Publishers Ltd., part of Springer Nature 2018

\begin{abstract}
The academic discipline of International Relations (IR) has long pondered the questions of what it means to act in international politics and who can do so. However, the particular way in which IR has approached the problem of agency has somewhat masked important dynamics in international politics. By approaching the question of agency as an analytical problem that needs to be resolved before engaging with empirical material, IR has failed to see that who can act is often uncertain and contested. This special issue examines the emergence of international agency as an empirical phenomenon. Rather than analysing what given agents do, the contributions study how practices, performances and networks create and transform agency. In this introductory article, we prepare the ground for this distinct approach to studying international politics. We review how IR has addressed the problem of agency, and we discuss three social-theoretical traditions that see agency as an emergent phenomenon: poststructuralism, performance studies and actor-network theory. Finally, we highlight four insights that emerge from the contributions and challenge how IR has traditionally imagined agency.
\end{abstract}

Keywords Agency · Agent-structure problem · Constructivism · International Relations theory $\cdot$ Performativity $\cdot$ Practice theory

Benjamin Braun

b.braun@mpifg.de

Sebastian Schindler

s.schindler@soz.uni-frankfurt.de

Tobias Wille

wille@soz.uni-frankfurt.de

1 Max Planck Institute for the Study of Societies, Paulstraße 3, 50676 Cologne, Germany

2 Cluster of Excellence 'The Formation of Normative Orders', Goethe University Frankfurt, Max-Horkheimer-Straße 2, 60323 Frankfurt, Germany 


\section{Introduction}

Who can act in international politics? Much contemporary research in the academic discipline of International Relations (IR) takes it for granted that certain entitiessuch as states, international organisations or their respective leaders-are capable of acting. It treats international agency - that is, the capacity to act in international politics - as analytically given. Its main concerns are the questions of what given international agents do and how their behaviour can be explained. Only rarely have IR scholars asked how international agents come into being in the first place. In this special issue, we move the constitution of international agency centre-stage. Rather than taking agency for granted, we inquire into how it is gained, contested and transformed in practice.

The practices examined in this special issue range from diplomatic negotiations to video games and hunger strikes; from political declarations to TV shows and academic conferences. While each contribution studies highly specific occurrences and events, together they forcefully demonstrate the need for a shift in perspective in the analysis of international politics. This shift in perspective allows us to reconsider two longstanding problems in IR: the levels-of-analysis problem and the agent-structure problem. Both problems are widely treated as analytical questions that need to be resolved before one begins empirical research (Singer 1961; Wendt 1987). In contrast, our special issue examines how these problems are confronted and solved in and through practice. In the analytical perspective we propose, agency is a practical achievement, and because there are many different contexts in which agency can emerge, we also encounter a wide variety of forms of agency in international politics. Collaboratively, we seek to extend our understanding of this variety. This requires that we start with a broad definition of agency as 'capacity to act', which will then be refined and given content by engaging with empirical material. Throughout this article, we use the term 'agent' to denote an entity that can act in a specific context and 'agency' as the corresponding ability to act. An 'actor' in our terminology is an identifiably human or collective subject that in principle can gain agency and thus become an agent in the context in question.

There is no agreement in social theory on how agency should be conceptualised. For some authors, agency is closely tied to the idea of a human subject with a history, intentions and the capacity to make his or her own decisions. In this view, 'a capacity for agency-for desiring, for forming intentions, and for acting creatively-is inherent in all humans' (Sewell 1992, p. 20; see also Emirbayer and Mische 1998). Others have tried to move beyond this anthropocentric understanding by conceiving of agency instead as the mere quality of being active or vibrant - a quality that is not reserved for human subjects (Barad 2003; Latour 2005; Bennet 2010; see Passoth et al. 2012). IR authors have used the term 'agency' in a variety of ways. As Colin Wight (2006, p. 178) observes, 'attributions of agency can change, not only within theories, but also within the space of a sentence'. Wight concludes that IR scholars are rarely clear about 'what agency is, what it means to exercise agency, or who and what might do so' (ibid.). In our view, this situation is not necessarily the result of a lack of analytical rigour. 
Instead, the variety of theoretical notions of agency used in IR reflects a variety of practical understandings of agency in the world. Our analytical interest is in how this practical variety influences international politics. By studying the constitution of agency as an empirical question, we seek to avoid attributions of agency on purely conceptual grounds, be it to human beings, states or other actors. Our goal is to understand how certain entities gain the ability to act-in other words, to be active and make a difference-in specific contexts of international politics.

The proposed shift in perspective-towards a view of agency as a practical achievement-does not imply that all analytical conceptualisations need to be abandoned. Nor is this an argument about the ontological primacy of practice. Our intention is to bring into view phenomena that are too often ignored in IR research-phenomena that remain analytically invisible if one starts with the assumption that agents already exist. This article thus, first and foremost, advocates an analytical shift in perspective, a shift that is supposed to help us explore and understand what, in our view, is a neglected but highly relevant aspect of international politics. We do not argue that agency is entirely up for grabs in every situation. We do, however, recognise that 'struggles over agency and its attribution are an important feature of social life' (Law 1991, p. 173). To do justice to this important feature of social life, an update of IR's analytical toolkit is necessary. Such an update is not merely of academic interest, but can also help us better understand and, ultimately, address some of the most pressing problems of contemporary international politics. As the contributions to this special issue demonstrate, the question of who can act is often a highly contested political issue, linked to attributions of moral responsibility, legal obligation and political representation (see also Schindler 2014). Studying agency as a practical achievement brings into view an aspect of many conflicts that is too often ignored, namely that they are about the identity and agency of those who are engaged in them (see Ringmar 1996a).

As we elaborate in this introductory article, the suggested update of IR's analytical toolkit can draw specifically on three distinct traditions of social thought that theorise how the 'doer' emerges from the 'deed' (Duvall and Chowdhury 2011, p. 338; see Butler 1990): poststructuralism, performance studies and actor-network theory. These bodies of literature highlight how social practices produce 'subjects', 'roles' or 'actants'. Important differences notwithstanding, they share a view of agency as relational, situational and reflexive (Bucher 2017; Emirbayer 1997; Jackson and Nexon 1999). While Ringmar, in the comment that concludes this special issue, emphasises the differences between these three traditions of social thought, we read them-for the purposes of this article-as contributions to a common agenda. We do so because we think that all three traditions help our contributors to open up new and interesting perspectives on the perennial questions of what it means to act in international politics and who can do so.

In what follows, we first discuss the two classic analytical problems that have structured the debate on agency in IR, and show how they constrain our theoretical imagination when it comes to the problem of agency. We then outline three social-theoretical traditions that see agency as a product of practice and have inspired innovative research in IR. Finally, we summarise how the special issue 
advances IR's understanding of agency by highlighting four insights that emerge from the contributions.

\section{The question of agency in IR}

Since its institutionalisation as an academic discipline, IR has pondered the question of who the relevant actors are and what it means to act in international politics. The following section traces this discussion, which has not always made explicit use of the term 'agency'. It demonstrates that IR has focused predominantly on the question of how given agents act, while largely neglecting how they become agents in the first place.

\section{The levels-of-analysis problem in IR}

Since the early days of the discipline, distinguishing between various levels of analysis has been a common analytical strategy in IR. This influential idea can be traced back to Waltz's (1959/2001) attempt to 'locate' the major causes of war by distinguishing three 'images' of international politics. An explanation may locate the causes of war 'within man, within the structure of the separate states, [or] within the state system' (ibid.: 12). Since then, many authors have refined Waltz's original categories, proposing a wide variety of levels and corresponding agents, such as individual human beings, bureaucracies, states, regions and the international system (Singer 1961; Hollis and Smith 1990; Buzan 1995). However, beyond the basic consensus that the levels of the state and the international system matter, there is no agreement in IR on what the relevant levels and, correspondingly, the relevant agents for an enquiry into the dynamics of international politics should be.

In individual cases, the research strategy of limiting the scope to a certain category of agents can be defended on pragmatic grounds. As the standard prescription for research designs, however, the idea of levels of analysis has constrained IR's theoretical imagination. In particular, the logic of the levels-of-analysis problem prompts the researcher to resolve the agency problem on theoretical grounds and before engaging with empirical material. Thus, in his classic contribution to the debate, Singer (1961, p. 90) argues that

the problem is really not one of deciding which level is most valuable to the discipline as a whole and then demanding that it be adhered to from now unto eternity. Rather, it is one of realising that there is this preliminary conceptual issue and that it must be temporarily resolved prior to any given research undertaking.

But if we 'temporarily' resolve the question of agency by theoretical assertion before actually looking at what we are interested in, we have already decided what kind of world we want to see: a world of states, say, or a world of individuals, or a world of competing bureaucracies. It becomes impossible to see how agency is constituted in practice. Moreover, even though Waltz and Singer stress that what they propose 
is an analytical distinction, it is easily mistaken for an ontological one. As Mabee (2007, p. 434) points out, there is a tendency in IR to 'reify these levels instead of seeing them as complementary ways of looking at particular research problems'.

In its early days, IR was a fairly state-centric enterprise. As a consequence, the levels of analysis appeared simply as different degrees of aggregation of one and the same thing: inter-state politics. The question was whether systemic phenomena such as war can best be explained by what individual political leaders do, by what states do or by the properties of the system that these states form. More recent developments in world politics have created a more complex picture. New actors have joined the cast of international politics and have challenged the state's leading role. Accordingly, studies have shown that norm entrepreneurs, NGOs or global economic actors can have agency in international politics (Finnemore and Sikkink 1998; Keck and Sikkink 1998), and that international organisations possess the capacity to act independently of their member-state principals (Barnett and Finnemore 2004; Martin 2006). However, the introduction of all these entities as potential agents of international politics has not challenged the predominant mode of dealing with the problem of agency, which is through theoretical assertion.

\section{The agent-structure problem in IR}

A promising avenue for the theorisation of agency was opened up when Wendt (1987) introduced the agent-structure problem into IR. At the core of this theoretical problem lies the question of whether agents shape social structures or vice versa (see Bourdieu 1977; Giddens 1984). Wendt criticised IR theories for resolving this problem by making one of the two elements into 'ontologically primitive units', arguing that they could not, as a result, 'explain the properties and causal powers of their primary units of analysis' (Wendt 1987, p. 337). Thus, theories that assume the agency of certain actors-as all rationalist approaches do-cannot explain where their 'causal powers' come from. Wendt's famous 'structurationist' (see Giddens 1984) proposal, which he later (Wendt 1999) elaborated into a comprehensive theory of international politics, is to conceive of agents and structures as 'mutually constitutive yet ontologically distinct entities' (Wendt 1987, p. 360). While the levels-of-analysis problem highlights the question of who the relevant agents are, the agency-structure problem highlights what it means to act in the face of structural constraints. In Wendt's account, international agents_-primarily states, in his view - are constrained by social structures, but also have the power, through their acts, to transform these same structures.

While the question of agency has, in one way or another, always occupied the discipline of IR, it was only when Wendt highlighted the constitution of agency in his discussion of the agent-structure problem that a process of explicit theoretical reflection began. Wendt (1987, p. 359) himself argues that an agent possesses three intrinsic capacities, namely 'to have a theoretical understanding (however inaccurate) of its activities', 'to reflexively monitor and potentially adapt its behavior' and 'to make decisions'. This is a fairly restrictive definition of agency, which explicitly differentiates social agents from 'non-sapient elements that comprise natural structures' 
(ibid.). Because it ties agency to consciousness and freedom, this conceptualisation ultimately necessitates Wendt's (1999, p. 215) later theoretical choice to assert that 'states are people too', in the sense that they are corporate beings 'to which we can properly attribute human qualities like identities, interests, and intentionality'.

Wendt (1987, p. 339) had initially pointed out that 'the organizing principles of the state system constitute states as individual choice-making units which are responsible for their actions'; in other words, the agency of international actors is shaped by the structure of the international system (see Jackson and Nexon 1999, p. 296). Consequently, however, he and others, in search of a middle road between positivist and post-positivist approaches in IR, limited their analyses to the constitution of identities and interests, while bracketing other aspects of agency (see the contributions in Katzenstein 1996). Proposals to endogenise corporate identity and study 'processes involving the appearance and disappearance of political actors as well as boundary transformations' (Cederman and Daase 2003, p. 6) went mainly unheard. As Fearon and Wendt (2002, p. 63, emphasis in the original) note, 'like rationalists, modern constructivists have been largely content to take as "exogenously given" that they were dealing with some kind of actor, be it a state, transnational social movement, international organization or whatever'. The middle road thus turned out to be a 'one-way street' in constitutive theory (Herborth 2004, p. 61, our translation; see also Sending 2002, 2016).

\section{Beyond the dualism of agent and structure}

Another critique of the structurationist programme of early constructivist IR makes a more radical departure. Less interested in how the meta-theoretical commitments of that programme are translated into actual theories of international politics, this critique has taken aim at the dualist conception of agency and structure itself. In a seminal contribution, the sociologists Emirbayer and Mische (1998, pp. 962-963) diagnosed that a fixation on the interpenetration of agency and structure had left social theory with a 'flat and impoverished conception' of agency. As we have seen above, such a diagnosis applied to much of the IR literature of the late 1990s. By asserting that agents and structures are mutually constitutive, structurationist IR scholars tended to reify both agents and structures as entities of distinct ontological qualities (Bucher 2017; Jackson and Nexon 1999). ${ }^{1}$ Echoing Emirbayer's (1997) call for a 'relational sociology', Jackson and Nexon (1999) proposed to put 'relations before states' and drew out the contours of a relational IR.

In contrast to most approaches in IR, which take certain entities as given and then study how they interact, relationalist accounts take interactions as their starting point and then study how patterns of such interactions (often also referred to as configurations, figurations or formations) bring about the seemingly stable elements of the social world, including entities with agential properties. This approach promises particular analytical purchase with regard to the problem of agency. As Jackson and

\footnotetext{
1 A related critique of the agent-structure dichotomy has been formulated by authors who focus on how narratives constitute and negotiate agency; e.g. Ringmar (1996b) and Suganami (1999).
} 
Nexon (1999, p. 308) point out, 'rather than simply examining what agents do, [processual relationalist] analysis can provide us with theories of what agents are and how their agency is produced and sustained'. Crucially, a relationalist perspective does not require an a priori definition of what exactly agency encompasses. 'Relationalism allows us to begin to see agency not as a singular, essential element but to disaggregate what we mean by "agency" into different aspects [...] which may not be constant for each and every "agent" (ibid.: 318).

Jackson and Nexon (1999) stressed that relational reasoning can be employed by both rationalists and constructivists. IR has since also witnessed the emergence of practice theory (Neumann 2002; Adler and Pouliot 2011; Bueger and Gadinger 2015), a family of approaches that explicitly understand themselves as relational (Nexon and Pouliot 2013). These approaches study 'socially recognized forms of activity, done on the basis of what members learn from others, and capable of being done well or badly, correctly or incorrectly' (Barnes 2001, p. 19; see Neumann 2013 , p. 87). It is a core concern for these approaches to conceptualise the constitution of agents as an effect of interactions: 'agency is a result of practice rather than its source' (Bially Mattern 2011, p. 72; see also Duvall and Chowdhury 2011, pp. 337-43).

This special issue is situated in, and intended as a contribution to, these literatures that aspires to transcend the dualism of agent and structure. Nonetheless, we pursue a more specific agenda. Our aim is to study empirically and grasp theoretically how agency is gained, contested and transformed in practice.

\section{Emergent agency in social theory and in IR}

In their attempts to theorise how agency emerges in and through practice, the contributors to this special issue draw on various theoretical resources. Several strands in social theory have tried to grasp agency as a practical achievement. While a comprehensive review of this literature is beyond the scope of this introductory article, this section will focus on those strands of thought that have inspired substantial bodies of research in IR, namely poststructuralism, performance studies and actor-network theory. ${ }^{2}$ In each case, we present central concerns and insights of these bodies of literature and discuss how they have been taken up in IR.

\section{Poststructuralism: the iteration of discourses and practices generates agency}

The notion of performativity is of crucial importance to poststructuralist thinking on agency. It harks back to the work of linguistic philosopher J. L. Austin (1962, 1979), who introduced the idea of the performative nature of certain utterances. Austin's starting point is that not all utterances refer to pre-existing realities. Rather than simply asserting a given fact, statements such as 'I apologize' perform these facts into

\footnotetext{
${ }^{2}$ For overviews of the three bodies of literature, see Loxley (2007), Alexander and Mast (2006) and Muniesa (2014).
} 
existence. In those cases, 'to say something is to do something' (Austin 1962, p. 12). While an important inspiration for most authors writing on performativity, Austin exerted a particularly strong influence on the work of poststructuralist scholars, such as Jacques Derrida and Judith Butler. Transferring the idea of performativity from the philosophy of language to political theory, they stress the uncertainties and instabilities of performative acts. Thus Derrida (1988) criticises Austin for ignoring the constitutive role that the risk of rupture plays in speech. Austin's predominant focus is on the conditions that make speech acts successful (in other words, the conditions that allow them to bring into being facts such as an apology or a marriage), and not on how and why speech acts fail. However, failure is, Derrida argues, constitutive of performativity. It is precisely because speech acts can go wrong that their successful utterance has performative effects, bringing into being facts that could be otherwise. Derrida extends this insight not only to speech, but also to social practice more generally. Judith Butler (1990, 1993) further pursues this line of argument, demonstrating that attributions of gender are based on reiterative practices that make what is historically contingent appear natural and fixed. From this perspective, practices stabilise agents, but never do so completely, leaving identities and the practices that underpin them open to appropriation and change.

Following the early adoption of poststructuralist ideas in IR (Der Derian and Shapiro 1989), poststructuralist conceptions of agency became highly influential in the discipline. Perhaps unsurprisingly, poststructuralist investigations of agency in IR have focused mainly on the state. David Campbell, for example, studies 'the state's performative constitution of identity', highlighting that it takes place at a series of different sites, ranging 'from foreign and security policies to crises of intervention, immigration strategies, the protocols of treaty-making, representational politics at the United Nations, and beyond' (Campbell 1998, p. 25f). In a similar spirit, Cynthia Weber employs the concept of performativity in order to denaturalise the sovereign nation-state. As 'subjects in process', sovereign nation-states are 'the ontological effects of practices which are performatively enacted' (Weber 1998, p. 78; 1999). The idea of the performative constitution of agency is also present-albeit often implicitly - in the broader literature on the construction of state identities. Here, the discourses that demarcate the boundaries between self and other constitute the state as a particular kind of agent (Neumann 1999; Ringmar 1996a). These discourses are performative not only because they identify possible dangers threatening the self, but also because they establish the state as the designated actor to deal with them. They perform state agency through the 'securitisation' of various policy sectors (Wæver 1995; Buzan et al. 1998; Balzacq 2005; Hagmann 2018) and protect what, following Giddens, has been termed the 'ontological security' of states (Huysmans 1998; Mitzen 2006; Steele 2008; Zarakol 2010). Others have identified such performances of agency at the level of regions rather than states (Hellmann et al. 2013; Lopez Lucia 2016).

In recent years, many poststructuralist IR scholars have turned to the study of practices. While some have taken Foucault's (1969/2002) lead and study discourses as 'discursive practices' (Lopez Lucia 2016), others have drawn a stronger line between the two concepts, acknowledging that discourse constitutes the precondition for action, but insisting that practices are key to understanding how politics 
unfolds dynamically (Neumann 2002; see also Adler and Pouliot 2011; Bueger and Gadinger 2015; Schindler and Wille 2015). Adler and Pouliot, for example, understand practices as 'competent performances', by which they mean that 'practices are socially meaningful patterns of action, which, in being performed more or less competently, simultaneously embody, act out, and possibly reify background knowledge and discourse in and on the material world' (Adler and Pouliot 2011, p. 4). As Duvall and Chowdhury (2011, p. 338) put it, practices are 'the means by which subjects are produced as such', which requires that scholars take seriously the 'dynamic of producing and performing collective subjects'.

\section{Performance studies: to act is to put on an act}

A second strand of social-theoretical thought strongly emphasises the 'theatrical' character of social action. Here, 'performance' is generally understood as a 'social process by which actors, individually or in concert, display for others the meaning of their social situation' (Alexander 2006, p. 32). Such performances comprise actions ranging from everyday rituals to grand theatrical performances (see Schechner 2004). The core elements of a performance are repertoires of meaning, their instantiation by the actor and reception by an audience: 'The actors borrow meanings from discourse, reaffirm these meanings through their performance, and then return them to discourse as the audience interprets the events staged before them' (Ringmar 2012, p. 2). This view has found different theoretical elaborations in different academic disciplines.

In one of the foundational texts of the performance studies literature, Erving Goffman (1959) argued that social action in Western culture can be understood as dramaturgical action. Actions are 'performances' in the theatrical sense of the term, and people are 'actors' in the sense of being 'impression managers' before an audience. Turner (1974, see also 1995), in another seminal contribution, highlighted 'liminal' ritualistic moments that produce a strong sense of solidarity among people ('communitas'), transcending status distinctions and normative restrictions. Closely related to Turner's work on community was the contemporaneous turn towards performances in linguistic anthropology and folklore studies. Here, scholars developed a framework - 'verbal art as performance' - that emphasised the dual nature of performance as both action and event (Hymes 1971; Bauman 1975).

More recently, cultural sociologist Jeffrey Alexander (2004) has developed an influential theory of social performances that draws on both Goffman's sociology of everyday dramaturgical action and Turner's theory of rituals. To a greater extent than his predecessors, Alexander emphasises that, while performances in traditional, small-scale social collectives are one thing, they work very differently in 'complex, segmented, and differentiated' societies (Alexander 2006, p. 32). Although rituals continue to play an essential part, both performers and audiences have become 'de-fused' from the ritual production. Where 're-fusion' fails, performances 'seem artificial and contrived, less like rituals than like performances in the pejorative sense' (ibid.). The reflexivist moment of Alexander's approach is of particular interest to students of performances in (international) politics, where large geographical 
and cultural distances often separate ritual leaders, participants and audiences. In the same volume, both Mast's (2006) analysis of the 'social drama' of the Clinton/ Lewinski affair and Rauer's (2006) study on German Chancellor Willy Brandt's kneeling at the Warsaw Memorial illustrate this potential of event-like performances to cross cultural boundaries and national borders.

In IR, scholars of different theoretical persuasions have harnessed the insights of Goffman, Turner and others. Goffman's work in particular makes it possible to bridge the rationalist-constructivist divide in the sense that 'actors do behave strategically, but strategic action mainly consists in the self-interested and manipulative use of performances and self-presentations, frames and arguments' (Schimmelfennig 2002, p. 425f). Thus Goffman's conception of performative action has found application in the work of both rationalists and constructivists (Barnett 1998; Schimmelfennig 2002; Adler-Nissen 2014). Towards the constructivist end of the spectrum, there has been growing interest in the 'embodied performances' emphasised by performance studies (Edkins and Kear 2013; Ringmar 2016; Wilcox 2015). For instance, Karin Fierke's (2013) work on political protest and acts of self-sacrifice shows that dramaturgical actions do have significant effects on the agents of international politics.

\section{Actor-network theory: agency as agencements}

A third strand of thought that conceives of agency as an effect of practices and that has inspired a considerable body of work in IR is actor-network theory. Actor-network theory originated in the late 1980s in Science and Technology Studies. Its early protagonists were Bruno Latour, Michel Callon and John Law (Callon 1986; Callon and Latour 1981; Latour 1987; Law 1994). The crucial theoretical move of this literature is to conceive of agency as a relational effect. The ability to act is not an intrinsic characteristic of an individual entity, but derives from its embeddedness in a network of links to other entities. Arguably, actor-network theory has received most attention for the provocative proposition that the emergent character of agency applies equally to human and non-human entities. According to actor-network theory, things can act, not just human beings. The reception of actor-network theory in IR has tended to overemphasise the point of non-human agency at the cost of neglecting its relationalism. Actor-network theory's contribution to social theory, however, lies not so much in the insight that things can act, but rather in its problematisation of what it means to act at all. While the early works in actor-network theory focused mainly on practices of knowledge production in the natural sciences, Callon's (1998, 2007) more recent work broadens the scope of Science and Technology Studies by applying the same perspective to the discipline of economics. Focusing on the performative role of economics in the making of economic agency, Callon urges economic sociologists to shift their attention from the economy's embeddedness in society to its embeddedness in economics. Rather than criticising economics for its unrealistic 'rationality' assumption, they should acknowledge that 'homo oeconomicus really does exist' (Callon 1998, p. 50). This type of agent exists, however, 
only as a result of practices that actively configure calculative agencies. Building on actor-network theory and borrowing a concept from Deleuze and Guattari, Callon locates calculative agency in agencements - 'combination[s] of heterogeneous elements that have been carefully adjusted to one another' (Callon 2007, p. 319 ), which notably include non-human elements, such as economic models and algorithms.

In IR, interest in actor-network theory's theoretical vocabulary has surged in recent years (Barry 2013; Best and Walters 2013; Passoth and Rowland 2015). Empirically, this perspective has been applied to issues such as international security (Aradau 2010; Schouten 2014), state failure (Schouten 2013), practices of torture (Austin 2016) and the use of concepts in the academic discipline of IR (Bueger and Bethke 2014). At the same time, Michel Callon's more recent work has sparked a wave of new research in International Political Economy on the performative role played by economic theories and models in the configuration of markets and economic agents (Braun 2016). In finance, this approach has cast new light on the agency of hedge funds (Hardie and MacKenzie 2007), institutional investors (Watson 2009) and central banks (Holmes 2014; Braun 2015). Similarly, 'everyday' financial agents, such as savers and investors, have been shown to be the products of performative practices and market devices (Langley 2008). While the insight that calculative agency exists, but only in the form of minutely constructed agencements, may be most obvious in the case of homo oeconomicus, this 'configurational' view of agency also applies to other areas of international politics. For instance, diplomatic agency is not achieved simply by appointing an ambassador-there must also be an embassy, infrastructure for (safe) communication and so on (Neumann 2011; Wille 2016).

In this section, we have traced three strands of social theory that inquire into the constitution of agency and inform the contributions to this special issue. The literatures surveyed here provide strong support for a research agenda that treats international agents not as pre-given subjects, but as the effect of diverse concrete practices.

\section{Theorising performances of agency}

We began this article by describing how two classic analytical problems- the levelsof-analysis problem and the agent-structure problem-hinder IR's theoretical imagination. We then outlined three theoretical perspectives that open up a view on how agency emerges. In this section, we highlight four insights that can be gained from the contributions to this special issue. The first two insights concern the two classic problems. We argue that these two problems are relevant not because solving them clears the way for empirical study, but because enactments of agency themselves produce specific, context-dependent solutions. From these two findings, two further insights follow. By studying agency as a practical achievement, the contributions to this special issue highlight the blind spots and exclusions of traditional conceptualisations of agency. In doing so, they point to the need for a reflexive and symmetrical approach to theorisations of agency. We discuss these four insights in turn. 


\section{Recasting the levels-of-analysis problem}

Despite its name, the levels-of-analysis problem is by no means purely analytical. This becomes evident, for instance, through Wille's (2018) analysis of Kosovo's participation in the Rambouillet conference in 1999. When the negotiators met for the first time, it was unclear whether 'Kosovo' actually was a participant in the conference. Several Kosovar factions had travelled to Rambouillet, disagreeing on who actually spoke for 'Kosovo'. However, 'Kosovo' needed to become a unitary international agent in order to render a successful conclusion of the conference possible. In tracing the contentious negotiation process that enabled the Kosovo Albanian participants to sign the final document in the name of 'Kosovo', Wille demonstrates that agency at the inter-state level is a precarious achievement of practice that cannot be taken for granted. In Rambouillet, the state system at first needed to be established as a 'level' on which agency can take place. In other words, a specific solution to the levels-of-analysis problem needed to be produced through negotiating manoeuvres, influence-taking and careful staging. The outcome of the conference-in other words, the final document that led, when the Serbian/Yugoslav government declared its non-agreement with the accords, to the bombing of Yugoslavia-ultimately depended on the success of this performance of agency.

Rather than resolving the levels-of-analysis problem prior to their 'research undertaking' (Singer 1961, p. 90), the contributions to this special issue start out from specific empirical observations. Further examples are the various appearances of Somali pirates (Bueger 2018) or the 'Polish plumber' (Noyes 2018). As Bueger argues, pirate agency is irreducible to one level of analysis, because its forms depend ultimately on the specific agencement that brings it about, be it the screening of a movie or the meeting of an international group of diplomats and military officers. Similarly, Noyes (2018) traces how the persona of the Polish plumber entered multiple stages on multiple analytical levels. The Polish plumber became a racialised other, a neoliberal exemplar, an agent of European revitalisation. He was distinctly not a fixed personality, but open to a variety of appropriations. Taking into account this openness to appropriation, we can better understand how the Polish plumber impacted politics in France and elsewhere. Noyes' analysis speaks symmetrically of individuals, groups, and nation-states. It raises the question of what becomes of the political agents of Western modernity-and in particular the unionised worker-in a deterritorialising world, in which the nation-state appears to be losing importance.

\section{Recasting the agent-structure problem}

The contributions to this special issue demonstrate that the agent-structure problem cannot be solved in purely analytical terms either. Rather, practices and events themselves produce specific relationships between agents and structures. For example, Abrahamsson and Dányi (2018) demonstrate that the idea of unrestrained agency played an important role in the hunger strike of 23 refugees in Brussels in 2012. Officials of the Belgian state sought to contain the hunger strike in a 'mode of doing politics' in which hunger strikers were 'responsible and rational subjects who are 
both willing and able to make informed choices about their lives' (Abrahamsson and Dányi 2018). This mode ('citizenship') was enacted when state officials asked the hunger strikers to sign a written declaration in which they asserted expressly that they did not want to be fed 'until death follows' (ibid.). This declaration was meant to cast the hunger strikers as agents who were completely in control of, and thus responsible for, their own fates-agents who, in other words, had full agency vis$\grave{a}$-vis the structures of the material world, notably their own bodies. However, as Abrahamsson and Dányi argue, this specific, rational-legal view of how agents relate to structures corresponds to a specific political framing of the hunger strike that the strikers ultimately tried to escape. Precisely by means of the physiological deterioration of their bodies, intensified by performances such as the sewing of their lips, the hunger strikers enacted another mode of doing politics that challenged the liberal understanding of agency. By becoming weaker, the hunger strikers became stronger, and in doing so their actions questioned the traditional way of conceiving the relationship between agent and structure.

Similarly, Bueger's (2018) analysis of pirate agency seeks to transcend the dualism of agent and structure. For him, agency does not emerge from the interplay between agents and one single structure. Rather, 'agency depends upon, and is the effect of, webs of relations set up in and through practice' (Bueger 2018). These webs of relations, or agencements, can be reconstructed empirically and by a variety of methods. Watching movies and playing computer games are, to Bueger, as helpful as the participant observation of international meetings, the writing of field notes and engagement with the academic literature on piracy. Using these methods he identifies six agencements that 'turn pirates into political, normative, security, legal, or economic subjects, or into structural symptoms' (ibid.). Each of these agencements thus positions the pirate differently vis-à-vis constraining structures, granting them varying degrees of freedom to act. From a romantic hero to a mere structural effect, the pirate can be anything, depending on the particular agencement.

Attempts to resolve the two classic problems of agency through theoretical assumption result in a limited view of agency. The contributions to this special issue show what such analytical approaches miss. Rather than replacing one narrow analytical solution by another, they show that enactments of agency create and transcend classic levels of analysis, and that they establish specific, often contested relationships of agents and structures. In the following, we discuss two more general insights that result from these findings.

\section{Recognising conceptual limitations and exclusions}

Classic social scientific conceptualisations of agency, notably those presupposing rationality, limit our view of what agency is and what it can be. Such accounts exclude several forms of agency that are examined in this issue. In her discussion of the figure of the Polish plumber, Noyes (2018) reveals the liberal presuppositions behind the modern conception of agency. This conception rests on the assumptions of rationality and reason. But the infrastructures of modernity are maintained by the 'folk'; in other words, people 'pronounced to be under the epistemological sway of 
tradition and therefore unfit for the deliberative arena' (Noyes 2018). These 'intimate Others' of the modern Self are 'not invited into the Habermasian coffeehouse' (ibid.). They are 'not credited with rationality and denied freedom of action' (ibid.). Noyes' insight resonates with calls in recent actor-network theory-inspired scholarship that a sensitivity to the historicity of our ideas of individual agency should caution us against "liberal dreams about "acting", infused as they are with civic notions of freedom and choice' (Abrahamsson et al. 2015, p. 11).

The limits of the modern view of agency are raised explicitly also in Abrahamsson and Dányi's discussion of the hunger strike, and in Bueger's tracing of pirate agency. For Abrahamsson and Dányi (2018), the hunger strike that took place in 2012 in Brussels 'showed the limitations of conceptualising liberal democratic politics as the clash of well-articulated arguments, made by disembodied and disembedded actors in a more-or-less neutral environment' (Abrahamsson and Dányi 2018). The hunger strike not only creates awareness about the limits of conceptions of civic agency; it seeks to transcend such limits altogether by means of an extreme form of bodily suffering. It is a mode of doing politics that 'involves bodies being made strong by being made weak; making oneself heard by remaining silent; and, paradoxically, acting by becoming passive' (Abrahamsson and Dányi 2018). For Bueger (2018), Somali piracy does not merely happen in the Indian Ocean. Its performances include computer games, contact group meetings and academic texts, as well as the researcher's writing of field notes. Piracy emerges in Bueger's text as a phenomenon that has no tight boundaries, but that spans global governance, local resistance, mass culture, folklore and academic practices.

In their seminal article on relationalism in IR, Jackson and Nexon (1999, p. 318) suggest that the concept of agency includes different aspects that 'may not be constant for each and every agent'. The contributions to the special issue show empirically that this is indeed the case. Conceptual 'aspects' of agency depend on the particular practices we examine. This is why purely analytical solutions to problems of agency ultimately express a partial view of the world. Such conceptualisations express the cultural consensus of a given time and place, rather than the objective nature of things. The contributions to this special issue make clear that it is necessary to move beyond conventional conceptualisations of agency in order to understand what it means to act in international politics and who can do so.

\section{The need for a reflexive and symmetrical approach}

The described conceptual exclusions point to the importance of reflexivity and symmetry in thinking about agency. By using the term 'reflexivity' we want to highlight the need to engage with the limits - as well as the politics — of our own, academic theorisations of agency. By referring to 'symmetry', we emphasise the need to take seriously non-academic notions of agency (which can be a means of achieving reflexivity). Reflexivity and symmetry are direct correlates of treating agency as the context-dependent result of specific practices, as we do in this special issue. A reflexive and symmetrical approach takes into account how those who 'do' international politics theorise their own doing. It treats their theories symmetrically; in 
other words, on a par with our own (academic) theories, yet without subscribing to a general relativism concerning the value of the different world views. In doing so, a reflexive and symmetrical approach helps us to understand how IR's own conceptualisations shape international practices (see Schindler 2014).

Reflexivity and symmetry are important aspects of Abrahamsson and Dányi's analysis, which ascribes theoretical significance to the thinking and acting of the hunger strikers. As Abrahamsson and Dányi (2018) argue, the hunger strike is 'a mode of doing politics that shifts the implications and repertoires of how we may come to think about and use the concept of agency'. The hunger strike is a distinct mode of doing politics that cannot be understood as long as one relies exclusively on such established notions of agency as citizenship, activism or party politics. By becoming weaker, the hunger strikers begin to lose what is traditionally understood as agency, namely the capacity to 'move, speak and make informed decisions' (ibid.). But this does not imply that the strike has no effects. Passivity, silence and weakness do not constitute a lack of agency. On the contrary, there can be no doubt that the hunger strike is a powerful political performance. Taking this performance seriously thus allows us to understand the limits of specific theorisations of agency. By studying the hunger strike, we come to understand a mode of doing that calls into question the existing theoretical accounts of agency. It leads us to see the hunger strikers as agents in their own right-as subjects whose (non-)utterances we as social scientists need to allow to resonate in our theorising of agency.

A symmetrical and reflexive perspective also plays a crucial role in the contribution that focuses explicitly on a classic locus of International Relations, the diplomatic negotiations at Rambouillet. Wille (2018) shows that there was a reflexive awareness among conference participants that the issue of Kosovo needed to be transformed into a matter of inter-state politics. Diplomats and politicians at Rambouillet had their own theories of agency, which guided their understanding of what needed to be done for Kosovo to become an agent of international politics. These practical theories are not unlike those of many IR theorists in that they accord predominance to the state as a unitary agent. This analytical premise became, for the Kosovars, a political premise that required them to overcome their differences in order to be able to act in international politics - in other words, to have international agency. By demonstrating the practical importance of a central assumption of traditional IR theory, Wille encourages us to take practitioners' theories seriously and to make them speak to our own.

\section{Conclusions}

In this introductory article, we have prepared the ground for what follows: four indepth studies of concrete practices and events in which agency is at stake. We began with an account of IR's conventional approach to agency: its attempt to resolve analytically two problems, the levels-of-analysis and the agent-structure problem. We then pointed out the theoretical limitations of this conventional approach from a relationalist and practice-theoretical perspective. Subsequently, we outlined three distinct social-theoretical traditions that share a view of agency as emerging from 
concrete practices and inform the contributions to this special issue. In the final section, we highlighted four insights that result from this special issue's turn to the study of specific practices and events. This turn allows us to understand solutions to the two classic problems of agency as unstable and contested products of practice and to make visible the conceptual exclusions as well as the performative character of conventional conceptualisations of agency in the social sciences.

This special issue concludes with a comment by Erik Ringmar (2018). Ringmar sympathises with the questions we ask, but is doubtful whether we have chosen the right theoretical tools-notably, post-structuralism and actor-network theory-to answer them. He asserts that in our accounts 'performativity is too much in the head and not enough in the body', while in his view practices are only 'vehicles of the imagination' and 'how we imagine agency and subjectivity depends ultimately on how our bodies interact with the world' (ibid.). This introduction is not the place to respond to Ringmar's challenges. We hope his critical reflections will encourage readers to take our collective project as a new starting point from which to inquire further into how practices generate and transform agency. We have argued in this introduction that this project can draw on several distinct, and indeed quite different, traditions of social theory. Rather than emphasising the differences between these traditions and their specific weaknesses, as Ringmar does, we have sought to highlight where they converge in order to sketch a common agenda- an agenda for studying how agency emerges from practices. While aware of the differences between the theoretical traditions, we highlight the commonalities because they allow us to challenge the longstanding practice in IR of starting each enquiry from the assumption that certain agents exist instead of examining how they come into being. This approach brings into view a range of new and important political phenomena and allows us to ask novel and interesting theoretical questions.

Acknowledgments We are grateful to Christopher Daase-who was a mentor for all three of us at different stages of our academic careers-for his enduring support for this project. We also owe much to Karin Fierke and want to thank her for her support and encouragement. Furthermore, we want to thank all participants in the workshop we organised in 2014 at the Cluster of Excellence 'The Formation of Normative Orders' in Frankfurt (Main)_among them the authors of this issue-for their comments and suggestions, as well as the Fritz Thyssen Foundation and Erasmus Mundus Joint Doctorate 'Globalisation, the EU, and Multilateralism (GEM)' for their generous financial support. Special thanks also go to Bud Duvall, Christian Reus-Smit and Erik Ringmar, as well as JIRD's reviewers and editorial team for their very helpful comments on different drafts of this introductory article.

\section{References}

Abrahamsson, Sebastian, Filippo Bertoni, Annemarie Mol, and Rebeca Ibáñez Martín. 2015. Living with Omega-3: New Materialism and Enduring Concerns. Environment and Planning D: Society and Space 33 (1): 4-19.

Abrahamsson, Sebastian, and Endre Dányi. 2018. Becoming Stronger by Becoming Weaker: The Hunger Strike as a Mode of Doing Politics. Journal of International Relations and Development (this issue). https://doi.org/10.1057/s41268-018-0140-6.

Adler, Emanuel, and Vincent Pouliot. 2011. International Practices. International Theory 3 (1): 1-36.

Adler-Nissen, Rebecca. 2014. Stigma Management in International Relations: Transgressive Identities, Norms, and Order in International Society. International Organization 68 (1): 143-176. 
Alexander, Jeffrey C. 2006. Cultural Pragmatics: Social Performance between Ritual and Strategy. In Social Performance: Symbolic Action, Cultural Pragmatics, and Ritual, ed. Jeffrey C. Alexander, Bernhard Giesen, and Jason L. Mast, 29-90. Cambridge: Cambridge University Press.

Alexander, Jeffrey C. 2004. Cultural Pragmatics: Social Performance Between Ritual and Strategy. Sociological Theory 22 (4): 527-573.

Alexander, Jeffrey C., and Jason L. Mast. 2006. Introduction: Symbolic Action in Theory and Practice: The Cultural Pragmatics of Symbolic Action. In Social Performance: Symbolic Action, Cultural Pragmatics, and Ritual, ed. Jeffrey C. Alexander, Bernhard Giesen, and Jason L. Mast, 1-28. Cambridge: Cambridge University Press.

Aradau, Claudia. 2010. Security That Matters: Critical Infrastructure and Objects of Protection. Security Dialogue 41 (5): 491-514.

Austin, John Langshaw. 1979. Performative Utterances. In John L. Austin: Philosophical Papers, third ed, ed. James O. Urmson, and Geoffrey J. Warnock, 233-252. Oxford: Oxford University Press.

Austin, John Langshaw. 1962. How to Do Things With Words, William James Lectures. Oxford: Clarendon Press.

Austin, Jonathan Luke. 2016. Torture and the Material-Semiotic Networks of Violence across Borders. International Political Sociology 10 (1): 3-21.

Balzacq, Thierry. 2005. The Three Faces of Securitization: Political Agency, Audience and Context. European Journal of International Relations 11 (2): 171-201.

Barad, Karen. 2003. Posthumanist Performativity: Toward an Understanding of How Matter Comes to Matter. Signs: Journal of Women in Culture and Society 28 (3): 801-831.

Barnes, Barry. 2001. Practice as Collective Action. In The Practice Turn in Contemporary Theory, ed. Theodore R. Schatzki, Karin Knorr-Cetina, and Eike von Savigny, 17-28. New York: Routledge.

Barnett, Michael. 1998. Dialogues in Arab Politics: Negotiations in Regional Order. New York: Columbia University Press.

Barnett, Michael, and Martha Finnemore. 2004. Rules for the World: International Organizations in Global Politics. Ithaca: Cornell University Press.

Barry, Andrew. 2013. The Translation Zone: Between Actor-Network Theory and International Relations. Millennium. Journal of International Studies 41 (3): 413-429.

Bauman, Richard. 1975. Verbal Art as Performance. American Anthropologist 77 (2): 290-311.

Bennett, Jane. 2010. Vibrant Matter: A Political Ecology of Things. Durham: Duke University Press.

Best, Jacqueline, and William Walters. 2013. Forum: "Actor-Network Theory" and International Relationality: Lost (and Found) in Translation. International Political Sociology 7 (3): 332-349.

Bially Mattern, Janice. 2011. A Practice Theory of Emotion for International Relations. In International Practices, ed. Emanuel Adler, and Vincent Pouliot, 63-86. Cambridge: Cambridge University Press.

Bourdieu, Pierre. 1977. Outline of a Theory of Practice. Cambridge: Cambridge University Press.

Braun, Benjamin. 2016. From Performativity to Political Economy: Index Investing, ETFs and Asset Manager Capitalism. New Political Economy 21 (3): 257-273.

Braun, Benjamin. 2015. Governing the Future: The European Central Bank's Expectation Management During the Great Moderation. Economy and Society 44 (3): 367-391.

Bucher, Bernd. 2017. Moving beyond the Substantialist Foundations of the Agency-structure Dichotomy: Figurational Thinking in International Relations. Journal of International Relations and Development 20 (2): 408-433.

Bueger, Christian. 2018. Performing Piracy: A Note on the Multiplicity of Agency. Journal of International Relations and Development (this issue). https://doi.org/10.1057/s41268-017-0122-0.

Bueger, Christian, and Felix Bethke. 2014. Actor-Networking the "Failed State": An Enquiry into the Life of Concepts. Journal of International Relations and Development 17 (1): 30-60.

Bueger, Christian, and Frank Gadinger. 2015. The Play of International Practice. International Studies Quarterly 59 (3): 449-460.

Butler, Judith. 1993. Bodies That Matter: On the Discursive Limits of 'Sex'. New York: Routledge.

Butler, Judith. 1990. Gender Trouble: Feminism and the Subversion of Identity. New York: Routledge.

Buzan, Barry. 1995. The Level of Analysis Problem in International Relations Reconsidered. In International Relations Theory Today, ed. Steve Smith and Ken Booth, 198-216. Oxford: Polity Press.

Buzan, Barry, Ole Waever, and Jaap de Wilde. 1998. Security. A New Framework for Analysis. Boulder: Lynne Rienner Publishers. 
Callon, Michel. 2007. What Does It Mean to Say That Economics Is Performative? In Do Economists Make Markets?: On the Performativity of Economics, ed. Donald A. MacKenzie, Fabian Muniesa, and Lucia Siu, 311-357. Princeton: Princeton University Press.

Callon, Michel. 1998. Introduction: The Embeddedness of Economic Markets in Economics. In Laws of the Markets, ed. Michel Callon, 1-57. Oxford: Blackwell.

Callon, Michel. 1986. Some Elements of a Sociology of Translation: Domestication of the Scallops and the Fishermen of St. Brieuc Bay. In Power, Action, and Belief: A New Sociology of Knowledge?, ed. John Law, 196-233. London: Routledge \& Kegan Paul.

Callon, Michel, and Bruno Latour. 1981. Unscrewing the Big Leviathan: How Actors Macro-Structure Reality and How Sociologists Help Them to Do So. In Advances in Social Theory and Methodology: Toward an Integration of Micro- and Macro-Sociologies, ed. Karin Knorr-Cetina, and Aaron Victor Cicourel, 277-303. Boston: Routledge \& Kegan Paul.

Campbell, David. 1998. National Deconstruction: Violence, Identity, and Justice in Bosnia. Minneapolis: University of Minnesota Press.

Cederman, Lars-Erik, and Christopher Daase. 2003. Endogenizing Corporate Identities: The Next Step in Constructivist IR Theory. European Journal of International Relations 9 (1): 5-35.

Der Derian, James and Michael J. Shapiro, eds (1989) International/Intertextual Relations: Postmodern Readings of World Politics, Lexington: Lexington Books.

Derrida, Jacques. 1988. 'Signature Event Context'. In Derrida: Limited Inc., ed. Gerald Graff, 1-23. Evanston: Northwestern University Press.

Duvall, Raymond D., and Arjun Chowdhury. 2011. Practices of Theory. In International Practices, ed. Emanuel Adler and Vincent Pouliot, 335-354. Cambridge: Cambridge University Press.

Edkins, Jenny, and Adrian Kear (eds.). 2013. International Politics and Performance: Critical Aesthetics and Creative Practice. New York: Routledge.

Emirbayer, Mustafa. 1997. Manifesto for a Relational Sociology. American Journal of Sociology 103 (2): 281-317.

Emirbayer, Mustafa, and Ann Mische. 1998. What Is Agency? American Journal of Sociology 103 (4): 962-1023.

Fearon, James and Alexander Wendt (2002) Rationalism v. Constructivism: A Skeptical View, in Walter Carlsnaes, Thomas Risse-Kappen and Beth A. Simmons, eds, Handbook of International Relations, 52-72, London: Sage.

Fierke, Karin M. 2013. Political Self-Sacrifice: Agency, Body and Emotion in International Relations. Cambridge: Cambridge University Press.

Finnemore, Martha, and Kathryn Sikkink. 1998. International Norm Dynamics and Political Change. International Organization 52 (4): 887-917.

Foucault, Michel. 2002. Archaeology of Knowledge. London: Routledge.

Giddens, Anthony. 1984. The Constitution of Society: Outline of the Theory of Structuration. Cambridge: Polity Press.

Goffman, Erving. 1959. The Presentation of Self in Everyday Life. Garden City: Doubleday.

Hagmann, Jonas. 2018. Securitisation and the Production of International Order(s). Journal of International Relations and Development 21 (1): 194-222.

Hardie, Iain, and Donald MacKenzie. 2007. Assembling an Economic Actor: The Agencement of a Hedge Fund. Sociological Review 55 (1): 57-80.

Hellmann, Gunther, Benjamin Herborth, Gabi Schlag, and Christian Weber. 2013. The West: A Securitising Community? Journal of International Relations and Development (forthcoming).

Herborth, Benjamin. 2004. 'Die via media als konstitutionstheoretische Einbahnstraße: Zur Entwicklung des Akteur-Struktur-Problems bei Alexander Wendt' [The via media as a one-way street in constitutional theory: On the development of the agent-structure problem in Alexander Wendt's work]. Zeitschrift für Internationale Beziehungen 11 (1): 61-87.

Hollis, Martin, and Steve Smith. 1990. Explaining and Understanding International Relations. Oxford: Clarendon Press.

Holmes, Douglas R. 2014. Economy of Words. Communicative Imperatives in Central Banks, Chicago: Chicago University Press.

Huysmans, Jef. 1998. 'Security! What Do You Mean? From Concept to Thick Signifier', European Journal of International Relations 4: 226-255.

Hymes, Dell. 1971. Competence and Performance in Linguistic Theory. In Language Acquisition: Models and Methods, ed. Renira Huxley, and Elisabeth Ingram, 3-28. London and New York: Academic Press. 
Jackson, Patrick Thaddeus, and Daniel H. Nexon. 1999. Relations Before States: Substance, Process and the Study of World Politics. European Journal of International Relations 5 (3): 291-332.

Katzenstein, Peter J. (ed.). 1996. The Culture of National Security: Norms and Identity in World Politics. New York: Columbia University Press.

Keck, Margaret E., and Kathryn Sikkink. 1998. Activists Beyond Borders: Advocacy Networks in International Politics. Ithaca: Cornell University Press.

Langley, Paul. 2008. The Everyday Life of Global Finance: Saving and Borrowing in Anglo-America. Oxford: Oxford University Press.

Latour, Bruno. 1987. Science in Action: How to Follow Scientists and Engineers Through Society. Cambridge, MA: Harvard University Press.

Latour, Bruno. 2005. Reassembling the Social: An Introduction to Actor-Network-Theory. Oxford: Oxford University Press.

Law, John. 1991. Power, Discretion and Strategy. In A Sociology of Monsters: Essays on Power, Technology and Domination, ed. John Law, 165-191. London: Routledge.

Law, John. 1994. Organizing Modernity. Oxford: Blackwell.

Lopez Lucia, Elisa (2016) 'Rethinking Regionalism and the Politics of Regionalisation: The Performance of ECOWAS's Agency by Nigeria and the European Union', Journal of International Relations and Development (forthcoming).

Loxley, James. 2007. Performativity. Abingdon: Routledge.

Mabee, Bryan. 2007. Levels and Agents, States and People: Micro-Historical Sociological Analysis and International Relations. International Politics 44 (4): 431-449.

Martin, Lisa L. 2006. Distribution, Information, and Delegation to International Organizations: The Case of IMF Conditionality. In Delegation and Agency in International Organizations, ed. Darren G. Hawkins, David A. Lake, Daniel L. Nielson, and Michael J. Tierney, 140-164. Cambridge: Cambridge University Press.

Mast, Jason L. 2006. The Cultural Pragmatics of Event-Ness: The Clinton/Lewinsky Affair. In Social Performance: Symbolic Action, Cultural Pragmatics, and Ritual, ed. Jeffrey C. Alexander, Bernhard Giesen, and Jason L. Mast, 115-145. Cambridge: Cambridge University Press.

Mitzen, Jennifer. 2006. Ontological Security in World Politics: State Identity and the Security Dilemma. European Journal of International Relations 12: 341-370.

Muniesa, Fabian. 2014. The Provoked Economy: Economic Reality and the Performative Turn. Abingdon: Routledge.

Noyes, Dorothy. 2018. Blaming the Polish Plumber: Phantom Agents, Invisible Workers, and the Liberal Arena. Journal of International Relations and Development (this issue). https://doi.org/10.1057/ s41268-017-0128-7.

Neumann, Iver B. 2013. Diplomatic Sites: A Critical Enquiry. London: Hurst.

Neumann, Iver B. 2011. At Home with the Diplomats: Inside a European Foreign Ministry. Ithaca: Cornell University Press.

Neumann, Iver B. 2002. Returning Practice to the Linguistic Turn: The Case of Diplomacy. MillenniumJournal of International Studies 31 (3): 627-651.

Neumann, Iver B. 1999. Uses of the Other: 'The East' in European Identity Formation. Manchester: Manchester University Press.

Nexon, Daniel H., and Vincent Pouliot. 2013. "Things of Networks": Situating ANT in International Relations. International Political Sociology 7 (3): 342-345.

Passoth, Jan-Hendrik, Birgit Peuker, and Michael Schillmeier. 2012. Introduction. In Agency without Actors? New Approaches to Collective Action, ed. Jan-Hendrik Passoth, Birgit Peuker, and Michael Schillmeier, 1-11. London: Routledge.

Passoth, Jan-Hendrik, and Nicholas J. Rowland. 2015. Who Is Acting in International Relations? In Human Beings in International Relations, ed. Daniel Jacobi, and Annette Freyberg-Inan, 266-285. Cambridge: Cambridge University Press.

Rauer, Valentin. 2006. Symbols in Action: Willy Brandt's Kneefall at the Warsaw Memorial. In Social Performance: Symbolic Action, Cultural Pragmatics, and Ritual, ed. Jeffrey C. Alexander, Bernhard Giesen, and Jason L. Mast, 257-282. Cambridge: Cambridge University Press.

Ringmar, Erik 2018. The Problem with Performativity: Comments on the Contributions. Journal of International Relations and Development (this issue).

Ringmar, Erik. 2016. How the World Stage Makes Its Subjects: An Embodied Critique of Constructivist IR Theory. Journal of International Relations and Development 19 (1): 101-125. 
Ringmar, Erik. 2012. Performing International Systems: Two East-Asian Alternatives to the Westphalian Order. International Organization 66 (1): 1-25.

Ringmar, Erik. 1996a. Identity, Interest and Action: A Cultural Explanation of Sweden's Intervention in the Thirty Years War. Cambridge: Cambridge University Press.

Ringmar, Erik. 1996b. On the Ontological Status of the State. European Journal of International Relations 2 (4): 439-466.

Schechner, Richard. 2004. Performance Theory. London: Routledge.

Schimmelfennig, Frank. 2002. Goffman Meets IR: Dramaturgical Action in International Community. International Review of Sociology 12 (3): 417-437.

Schindler, Sebastian. 2014. Man versus State: Contested Agency in the United Nations. MillenniumJournal of International Studies 43 (1): 3-23.

Schindler, Sebastian, and Tobias Wille. 2015. Change in and through practice: Pierre Bourdieu, Vincent Pouliot, and the end of the Cold War. International Theory 7 (2): 330-359.

Schouten, Peer. 2014. Security as Controversy: Reassembling Security at Amsterdam Airport. Security Dialogue 45 (1): 23-42.

Schouten, Peer. 2013. The Materiality of State Failure: Social Contract Theory, Infrastructure and Governmental Power in Congo. Millennium-Journal of International Studies 41 (3): 553-574.

Sending, Ole Jacob. 2016. Agency, Order, and Heteronomy. European Review of International Studies 3 (3): 63-75.

Sending, Ole Jacob. 2002. Constitution, Choice and Change: Problems with the "Logic of Appropriateness" and Its Use in Constructivist Theory. European Journal of International Relations 8 (4): 443-470.

Sewell Jr., William H. 1992. A Theory of Structure: Duality, Agency, and Transformation. American Journal of Sociology 98 (1): 1-29.

Singer, J. David. 1961. The Level-of-Analysis Problem in International Relations. World Politics 14 (1): 77-92.

Steele, Brent J. 2008. Ontological Security in International Relations: Self-Identity and the IR State. Abingdon: Routledge.

Suganami, Hidemi. 1999. Agents, Structures, Narratives. European Journal of International Relations 5 (3): 365-386.

Turner, Victor W. 1995. The Ritual Process: Structure and Anti-Structure, Lewis Henry Morgan Lectures 1966. New York: Aldine de Gruyter.

Turner, Victor W. 1974. Dramas, Fields, and Metaphors: Symbolic Action in Human Society. Ithaca: Cornell University Press.

Wæver, Ole. 1995. Securitization and Desecuritization. In On Security, ed. Ronnie D. Lipschutz, 46-86. New York: Columbia University Press.

Waltz, Kenneth N. (1959/2001) Man, the State, and War: A Theoretical Analysis, New York: Columbia University Press.

Watson, Matthew. 2009. Investigating the Potentially Contradictory Microfoundations of Financialization. Economy and Society 38 (2): 255-277.

Weber, Cynthia. 1999. Faking It: US Hegemony in a 'Post-Phallic' Era. Minneapolis: University of Minnesota Press.

Weber, Cynthia. 1998. Performative States. Millennium_Journal of International Studies 27 (1): 77-95.

Wendt, Alexander. 1999. Social Theory of International Politics. Cambridge: Cambridge University Press.

Wendt, Alexander. 1987. The Agent-Structure Problem in International Relations Theory. International Organization 41 (3): 335-370.

Wight, Colin. 2006. Agents, Structures and International Relations: Politics as Ontology. Cambridge: Cambridge University Press.

Wilcox, Lauren B. 2015. Bodies of Violence: Theorizing Embodied Subjects in International Relations. Oxford: Oxford University Press.

Wille, Tobias. 2018. Representation and Agency in Diplomacy: How Kosovo Came to Agree to the Rambouillet Accords. Journal of International Relations and Development (this issue). https://doi. org/10.1057/s41268-017-0120-2.

Wille, Tobias. 2016. Diplomatic Cable. In Making Things International 2: Catalysts and Reactions, ed. Mark B. Salter, 166-178. Minneapolis: University of Minnesota Press.

Zarakol, Ayşe. 2010. Ontological (In)security and State Denial of Historical Crimes: Turkey and Japan. International Relations 24 (1): 3-23. 
Benjamin Braun is a senior researcher at the Max Planck Institute for the Study of Societies in Cologne. His research focuses on the political economy of central banking and, more recently, on asset management.

Sebastian Schindler is a research associate in the Cluster of Excellence 'The Formation of Normative Orders' at Goethe University Frankfurt. His research focuses on the spread of cynicism and suspicion in international politics.

Tobias Wille is a research associate in the Cluster of Excellence 'The Formation of Normative Orders' at Goethe University Frankfurt. He recently completed a PhD thesis on the history of Kosovo's diplomacy. 